\title{
LAYANAN BIMBINGAN KELOMPOK TERHADAP PEMBENTUKAN PEMAHAMAN BAHAYA PERNIKAHAN DINI SISWA SMP DI MUKOMUKO
}

\author{
Rati Putri, Syahriman, Afifatus Sholihah \\ Prodi Bimbingan dan Konseling Fakultas Keguruan dan Ilmu Pendidikan \\ Universitas Bengkulu \\ ratiputri93@gmail.com, syahriman@unib.ac.id, afifatus@unib.ac.id
}

\begin{abstract}
ABSTRAK
Penelitian ini bertujuan untuk mendeskripsikan pengaruh layanan bimbingan kelompok terhadap pembentukan pemahaman bahaya pernikahan dini siswa kelas VIII 4 SMP Negeri 02 Mukomuko. Metode yang digunakan dalam penelitian ini adalah metode eksperimen dengan desain penelitian one group pre-test dan post-test design. Sampel dalam penelitian ini adalah 10 siswa dari kelas VIII 4 yang memiliki tingkat pemahaman rendah dan sangat rendah tentang bahaya pernikahan dini. Teknik pengumpulan data menggunakan tes, wawancara dan observasi. Hasil penelitian ini menunjukkan pemahaman siswa terhadap bahaya pernikahan dini meningkat setelah diberikan layanan bimbingan kelompok, hal ini terlihat dari mean pre-test $=15,4$ dan mean post-test $=28,8$ dengan rata-rata peningkatan skor sebesar 13,6. Hasil perhitungan statistik uji Wilcoxon menunjukkan nilai $\mathrm{Z}=-2,809$ ( $p$ $=0,005<0,05)$ sehingga Ho ditolak, dapat disimpulkan terdapat pengaruh layanan bimbingan kelompok terhadap pembentukan pemahaman bahaya pernikahan dini siswa kelas VIII 4 SMP Negeri 02 Mukomuko. Artinya, pembentukan pemahaman siswa terhadap bahaya pernikahan dini semakin bagus jika lebih sering diberikan layanan bimbingan kelompok.
\end{abstract}

Kata kunci: bimbingan kelompok, pemahaman bahaya pernikahan dini

\section{THE EFFECT OF GROUP GUIDANCE SERVICE ON THE UNDERSTANDING ESTABLISHMENT DANGER OF EARLY MARRIAGE STUDENTS OF SMP MUKOMUKO}

\begin{abstract}
The study was aimed to describe the effect of group guidance service on the Establishment of Understanding danger of early marriage at class VIII 4 students of SMP Negeri 02 Mukomuko. The method used in this study was experimental method with one group pretest and posttest design. The subject of this study were 10 students of Class VIII 4 with low and very low category level understanding on the danger of early marriage. The data collection techniques were test, interview and observation. The result of this study showed that the stu ent's understanding on the danger of early marriage was improved after group guidance is given, it was showed from the mean score of pretest was $=15,4$ and mean posttest was $=28,8$ with the average score increase 13,6. The calculation of Statistic Wilcoxon test showed Z value $=-2,809(p=0,005<0,05)$. So $\mathrm{H}_{\mathrm{o}}$ was rejected, it can be concluded that there is the effect of group guidance service on the establishment of understanding danger of early marriage at Class VIII 4 students of SMP Negeri 02 Mukomuko. It means, students' understanding establishment danger of early marriage becomes better if more often given group guidance.
\end{abstract}

Keywords: Group guidance, Understanding danger of early marriage 


\section{Pendahuluan}

$\begin{array}{crr}\text { Sekolah } & \text { merupakan lembaga } \\ \text { pendidikan yang berfungsi } & \text { untuk }\end{array}$ memberikan layanan kepada peserta didik agar memperoleh pengetahuan dan kemampuan akademik yang dibutuhkan dalam kehidupannya (Ali, 2009: 355). Selain itu, pengetahuan di luar akademik yang urgen bagi masa perkembangan peserta didik juga penting diberikan, terutama bagi peserta didik yang sedang menginjak usia remaja.

Pada masa remaja, peserta didik diharapkan mampu memahami tentang dunia remaja, diantaranya mengenai seks, seksualitas dan kesehatan reproduksi (YKP, 2016: 14). Pembahasan perihal seks dalam keluarga, masyarakat dan sosial budaya masih dianggap tabu. Informasi yang salah dan kurangnya pemahaman tentang seks dapat mendorong remaja terjerumus pada seks bebas yang berujung pada pernikahan dini.

Undang-undang No.1 Tahun 1974 tentang Perkawinan Bab II pasal 7 ayat 1 menyatakan bahwa perkawinan hanya diizinkan jika pihak pria sudah mencapai umur 19 tahun dan pihak wanita mencapai umur 16 tahun (UU Perkawinan No.1 Tahun 1974). Selanjutnya UU No.23 Tahun 2002 menyatakan usia di bawah 18 tahun dikategorikan sebagai anak (UU Perlindungan Anak No.23 Tahun 2002).

Sementara itu, Badan Kependudukan dan Keluarga Berencana Nasional (BKKBN) mensosialisasikan usia ideal menikah yaitu di atas 21 tahun bagi perempuan dan 25 tahun bagi laki-laki (BKKBN, 2016). Namun demikian, kenyataan di lapangan menunjukkan masih banyak terjadi pernikahan di bawah usia yang ditetapkan Undang-undang maupun BKKBN.

Fakta pernikahan anak di Indonesia menurut laporan International Centre for Research (ICRW) tahun 2014 bahwa Indonesia termasuk negara dengan persentase pernikahan usia muda tertinggi di dunia (ranking 37 dari 73 negara dengan pernikahan dini tertinggi) dan tertinggi kedua di ASEAN (Sunaryanto, dkk., 2016: 2). Sementara itu, di Provinsi Bengkulu berdasarkan hasil Riset Kesehatan Dasar (2010) pada pernikahan kelompok umur 1014 tahun, Bengkulu menempati tertinggi nomor 6 se-Indonesia (Sunaryanto, dkk., 2016: 3).

Riset Kependudukan dan Kebijakan Universitas Bengkulu tahun 2016 melaporkan bahwa kabupaten di Bengkulu dengan persentase tertinggi yang menikah di bawah usia 17 tahun adalah Kabupaten 
Mukomuko, yaitu sebesar 18,34\% (Hanum, 2016 ; RBO, 14 November 2016).

Masyarakat Kabupaten Mukomuko umumnya tinggal di daerah pedesaan yang didominasi oleh suku Mukomuko dan Pekal sebagai suku asli. Tradisi kawin muda masih melekat pada kedua suku ini. Hal tersebut terlihat dari banyaknya remaja suku Pekal yang menikah pada usia 13-15 tahun sebelum menyelesaikan pendidikan tingkat SMP maupun usia 16-17 tahun.

Pernikahan dini berdampak pada kematian bayi, kematian ibu, perceraian, KDRT dan angka putus sekolah (Sunaryanto, 2016:2). Mengingat dampak tersebut, pemerintah melakukan sosialisasi kepada masyarakat dan di sekolah. Upaya pencegahan penting dilakukan di sekolah, mengingat pelaku pernikahan dini banyak berasal dari remaja yang putus sekolah dan remaja tersebut kurang mendapatkan pemahaman mengenai bahaya pernikahanan dini.

Berdasarkan hasil wawancara dengan guru BK SMPN 02 Mukomuko pada 14 Februari 2017, terdapat beberapa siswa yang putus sekolah lalu menikah dini serta belum pernah dilakukan layanan bimbingan kelompok mengenai bahaya pernikahan dini kepada siswa. Minimnya tenaga guru BK yang berkualifikasi BK di sekolah tersebut menyebabkan pelayanan BK belum terlaksana secara optimal. Kenyataan tersebut dapat menyebabkan siswa kurang mendapatkan pemahaman mengenai bahaya pernikan dini. Disinilah pentingnya peran guru BK di sekolah untuk memberikan pemahaman kepada siswa melalui berbagai layanan BK di sekolah.

Salah satu layanan bimbingan dan konseling yang memiliki indikasi untuk memberikan pemahaman dan pengetahuan terhadap suatu pemikiran yang dapat mengendalikan perilaku dalam situasi kelompok untuk menemukan sebuah pemikiran baru adalah layanan bimbingan kelompok (Cholipah, 2013:16).

Dalam kegiatan bimbingan kelompok dibahas topik permasalahan secara meluas dan mendalam melalui dinamika kelompok sehingga dengan tercapainya dinamika kelompok yang intensif akan mendorong pengembangan perasaan, pikiran, persepsi, wawasan, dan sikap yang menunjang diwujudkannya tingkah laku yang lebih efektif (Prayitno, 2012: 2-3).

Selain itu, dalam bimbingan kelompok terdapat fungsi pemahaman dan pencegahan, melalui layanan tersebut, secara tidak langsung akan meningkatkan keterampilan komunikasi dan pemahaman siswa. Dengan demikian, siswa akan lebih 
mudah mengkomunikasikan kepada temanteman lainnya sehingga pencegahan bisa menjangkau lebih luas dan berkelanjutan.

Mengingat pentingnya pemahaman siswa mengenai bahaya pernikahan dini dan tingginya angka pernikahan dini di Kabupaten Mukomuko, maka penulis tertarik untuk melakukan penelitian dengan judul "Pengaruh Layanan Bimbingan Kelompok terhadap Pembentukan Pemahaman bahaya Pernikahan Dini Siswa Kelas VIII 4 SMP Negeri 02 Mukomuko".

Rumusan masalah dalam penelitian ini yaitu bagaimana pengaruh layanan bimbingan kelompok terhadap pembentukan pemahaman bahaya pernikahan dini siswa Kelas VIII 4 SMPN 2 Mukomuko?. Sedangkan tujuan penelitian adalah untuk mendeskripsikan pengaruh layanan bimbingan kelompok terhadap pembentukan pemahaman bahaya pernikahan dini Siswa Kelas VIII 4 SMPN 02 Mukomuko.

\section{Metode Penelitian}

Metode penelitian adalah kuantitatif dengan jenis penelitian eksperimen (preeksperimen) desain one group pretestpostest design. Sampel dalam penelitian ini adalah siswa yang memiliki pemahaman rendah dan sangat rendah terhadap bahaya pernikahan dini di kelas VIII 4 SMPN 02 Mukomuko. Teknik pengumpulan data yang digunakan dalam penelitian ini yaitu dengan instrument tes pemahaman bahaya pernikahan dini, wawancara dan observasi.

\section{Hasil dan Pembahasan}

Hasil pre-test pemahaman bahaya pernikahan dini siswa Kelas VIII 4 selengkapnya dapat dillihat pada Tabel 1 berikut.

Tabel 1.

Hasil pre-test pemahaman

\begin{tabular}{cccc}
\hline No & $\begin{array}{l}\text { Inisial } \\
\text { Responden }\end{array}$ & $\begin{array}{c}\text { Skor } \\
\text { Pre- } \\
\text { test }\end{array}$ & Keterangan \\
\hline 1 & AND & 16 & Rendah \\
2 & ANR & 14 & $\begin{array}{c}\text { Sangat } \\
\text { Rendah }\end{array}$ \\
3 & ANY & 15 & Rendah \\
4 & ETK & 17 & Rendah \\
5 & RDK & 16 & Rendah \\
6 & RIZ & 17 & Rendah \\
7 & RON & 12 & Sangat \\
& & & Rendah \\
8 & RUL & 13 & Sangat \\
& & & Rendah \\
9 & TIA & 15 & Rendah \\
10 & YUL & 17 & Rendah \\
Jumlah & & 154 & \\
Rata-rata & & 15,4 & Rendah \\
\hline
\end{tabular}


Berdasarkan hasil pre-test pada tabel tersebut dapat disimpulkan bahwa pemahaman terhadap bahaya pernikahan dini pada 10 siswa kelas VIII 4 sebelum diberikan layanan bimbingan kelompok dijumpai 7 siswa berada dalam kategori rendah dan 3 siswa dalam kategori sangat rendah dengan rata-rata pemahman siswa 15,4 yaitu berada dalam kategori rendah.

Hasil post-test pemahaman ba-haya pernikahan dini siswa kelas VIII 4 setelah diberikan layanan bimbingan kelompok sebanyak 5 kali pertemuan selengkapnya dapat dilihat pada Tabel 2 berikut.

Tabel 2.

Hasil post-test pemahaman bahaya pernikahan dini siswa Kelas VIII 4

\begin{tabular}{cccc}
\hline No & $\begin{array}{c}\text { Inisial } \\
\text { Responden }\end{array}$ & $\begin{array}{c}\text { Skor } \\
\text { Post- } \\
\text { test }\end{array}$ & $\begin{array}{c}\text { Keterang } \\
\text { an }\end{array}$ \\
\hline $\mathbf{1}$ & AND & 28 & $\begin{array}{c}\text { Sangat } \\
\text { Tinggi }\end{array}$ \\
$\mathbf{2}$ & ANR & 26 & Tinggi \\
$\mathbf{3}$ & ANY & 25 & Tinggi \\
$\mathbf{4}$ & ETK & 30 & $\begin{array}{c}\text { Sangat } \\
\text { Tinggi }\end{array}$ \\
$\mathbf{5}$ & RDK & 33 & $\begin{array}{c}\text { Sangat } \\
\text { Tinggi }\end{array}$ \\
$\mathbf{6}$ & RIZ & 33 & $\begin{array}{c}\text { Sangat } \\
\text { Tinggi }\end{array}$ \\
$\mathbf{7}$ & RON & 25 & Tinggi \\
$\mathbf{8}$ & RUL & 24 & Tinggi \\
$\mathbf{9}$ & TIA & 32 & $\begin{array}{c}\text { Sangat } \\
\text { Tinggi }\end{array}$ \\
& & & Sangat \\
$\mathbf{1 0}$ & YUL & 32 & Tinggi \\
\hline
\end{tabular}

\begin{tabular}{lcc}
\hline Jumlah & 288 & \\
Rata-rata & 28,8 & $\begin{array}{c}\text { Sangat } \\
\text { Tinggi }\end{array}$ \\
\hline
\end{tabular}

Berdasarkan hasil post-test pada Tabel 2, setelah diberikan layanan bimbingan kelompok, pemahaman siswa terhadap bahaya pernikahan dinI meningkat, 4 siswa yaitu ANR, ANY, RON dan RUL berada dalam kategori tinggi dan 6 siswa yaitu AND, ETK, RDK, RIZ, TIA dan YUL berada dalam kategori sangat tinggi. Maka dapat disimpulkan bahwa pemahaman terhadap bahaya pernikahan dini pada 10 siswa kelas VIII 4 setelah diberikanlayanan bimbingan kelompok termasuk dalam kategori sangat tinggi dengan nilai rata-rata 28,8 .

Meningkatnya pemahaman siswa juga terlihat dari dinamika kelompok yang terjadi dalam proses kegiatan. Pada pertemuan pertama siswa hanya diam ketika dimintai pendapat, namun pada pertemuan selanjutnya menjadi lebih aktif dan terbuka.

Berdasarkan tabel perbandingan pretest dan post-test maka dapat diketahui bahwa dari 10 siswa tersebut mengalami peningkatan pemahaman terhadap bahaya pernikahan dini. Rata-rata skor pre-test sebelum mendapatkan layanan bimbingan kelompok adalah 15,4 dan termasuk 
kategori rendah. Namun, pada post-test setelah mendapatkan layanan bimbingan kelompok rata-rata skor tersebut mengalami peningkatan yaitu sebesar. menjadi 28,8 termasuk dalam kategori sangat tinggi

Dalam penelitian ini uji hipotesis dilakukan untuk mengetahui apakah terdapat perbedaan pemahaman siswa sebelum dan setelah dilakukan bimbingan kelompok. Hasil statistik uji Wilcoxon yang telah dilakukan mendapatkan nilai $\mathrm{Z}=$ 2,809 dengan signifikansi (2-tailed) 0,05 (5\%). Nilai $\mathrm{p}=0,005<0,05$ maka $\mathrm{H}_{\mathrm{o}}$ ditolak. Dapat disimpulkan bahwa terdapat pengaruh layanan bimbingan kelommpok terhadap pemahaman Sepuluh siswa bahaya pernikahan dini siswa kelas VIII 4 SMPN 2 Mukomuko.

Sebelum diberikan layanan bimbingan kelompok para siswa menunjukkan tingkat pemahaman masih rendah. Hal ini terlihat dari proses kegiatan bimbingan kelompok siswa kurang aktif, diam dan belum terbuka untuk mengemukakan pendapat terkait topik yang dibahas, hal serupa juga diungkapkan oleh guru BK bahwa ketika diberikan layanan informasi mengenai pernikahan dini siswa banyak yang pasif, kurang memperhatikan dan tidak antusias terhadap masalah pernikahan dini.
Kemudian setelah mendapatkan layanan bimbingan kelompok dengan materi bahaya pernikahan dini dalam bidang psikologis, kesehatan, pendidikan, ekonomi, dan sosial budaya terbukti mampu meningkatkan pemahaman pada siswa. Hal ini terlihat selama proses bimbingan kelompok dimana siswa mulai menunjukkan minatnya dalam pembahasan materi, berusaha mencari informasi sendiri terkait materi, berani mengemukakan pendapat dan bercerita terkait materi saat membahas topik dalam bimbingan kelompok.

Berdasarkan hal tersebut, artinya semakin sering diberikan layanan bimbingan kelompok kepada siswa, maka pemahaman siswa terhadap bahaya pernikahan dini semakin bagus.

Pada tahap pengakhiran kegiatan bimbingan kelompok, ada beberapa kesan yang diungkapkan oleh anggota kelompok diantaranya yaitu dalam kegiatan layanan bimbingan kelompok ini dapat bermanfaat karena dapat menambah wawasan, pengetahuan tentang bahaya pernikahan dini, dapat memotivasi untuk belajar dan sekolah ke jenjang lebih tinggi serta menghindari diri dari pernikahan dini. 
Kebijakan Universitas Bengkulu.

\section{Kesimpulan}

Berdasarkan hasil penelitian, analisis data dan uji hipotesi yang telah dilakukan, maka dapat disimpulkan sebagai berikut:

1. Pemahaman siswa mengenai bahaya pernikahan dini sebelum diberikan layanan bimbingan kelompok berada dalam kategori rendah.

2. Pemahaman siswa mengenai bahaya pernikahan dini setelah diberikan layanan bimbingan kelompok, berada dalam kategori sangat tinggi.

3. Terdapat pengaruh layanan bimbingan kelompok terhadap pembentukan pemahaman bahaya pernikahan dini siswa kelas VIII 4 SMP Negeri 02 Mukomuko.

\section{Daftar Pustaka}

Ali, Mohammad. (2009). Pendidikan untuk Pembangunan Nasional: Menuju Bangsa Indonesia Mandiri dan Berdaya Saing Tinggi. Jakarta: Grasindo.

Cholipah Siti N, Supriyono \& Setyowani Ninik. (2013). Meningkatkan Pemahaman Orang Tua terhadap Pernikahan Dini Melalui Layanan Bimbingan Kelompok. Jurnal IJGC. Vol. 2, Nomor 2 (16-22).

Hanum, Sri Handayani. (2016). Pernikahan Usia Belia. Riset Kependudukan dan
FISIP: Universitas Bengkulu.

Prayitno. (2004). L.1-L.9. FKIP: Universitas Negeri Padang

Radar Bengkulu Online (2016, 14 November). Pernikahan Dini di Mukomuko Tertinggi Se-Provinsi Bengkulu. Diakses dari http://www.radarbengkuluonline.com

Sunaryanto Heri, Widiono S. \& Arwani M. Marwan. (2016). Analisis Faktor Penyebab Perkawinan Anak di Bengkulu dalam Perspektif Keluarga dan Masyarakat. Laporan Penelitian Pengabdian Masyarakat. Fakultas Ilmu Sosial dan Ilmu Politik: Universitas Bengkulu.

Undang-undang No.1 Tahun 1974 tentang Perkawinan.

UNFPA, (2012). Marrying Too Young ; End Child Marriage. Published by the United Nations Population Fund (UNFPA) : New York.

UNICEF, (2008). Child Marriage and The Law. UN-Plaza : New York.

Yayasan Kesehatan Perempuan. (2016). Memangkas Pernikahan Anak: Pengalaman Lapangan di Bondowoso Jawa Timur. Jakarta: Perpustakaan Nasional. 